\title{
Insanity, Sexuality, and the Gallows in Late Nineteenth-Century Iowa: The Case of Chester Bellows
}

\author{
Michael J. Pfeifer
}

ON DECEMBER 16, 1887, Floyd County Sheriff W. F. Clark hanged Chester Bellows in Charles City, Iowa, as a crowd of several hundred people waited outside an enclosed scaffold. The twenty-eight-year-old farmhand had been convicted of the July 1886 murder of sixteen-year-old Alice Waterman. Threatened with lynching, the condemned man had been tried and convicted without incident in November $1886 .{ }^{1}$

The case of Chester Bellows provides uncommon insight into Iowa's criminal justice system in the late nineteenth century and is interesting on several levels. ${ }^{2}$ The hanging was the first legal execution in the Hawkeye State since the 1860s, and it

1. Governor's Correspondence on Criminal Matters, Chester Bellows File, GII 393, folder 2, State Historical Society of Iowa, Des Moines (hereafter cited as CBF; documents are in folder 2 unless otherwise specified); Floyd County Advocate, 15 December 1887; Iowa State Register, 16 and 17 December 1887.

2. The transcript of Bellows's trial, which is preserved in the Governors' Correspondence on Criminal Matters in the State Archives in Des Moines, is a rare instance of a complete surviving record of a nineteenth-century criminal court proceeding. The Bellows File in the Governor's Correspondence, which includes the trial transcript, is a classified document under Iowa law.

I thank archives associate Ellen Sulser for helping me obtain permission from Iowa Governor Terry Branstad's office to use the Chester Bellows file and several other files of death row inmates. I am also indebted to Marvin Bergman and several anonymous readers for their comments, and to the State Historical Society of Iowa, which supported the research and writing of this essay through a research grant.

THE ANNALS OF IOWA 57 (Fall 1998). (CThe State Historical Society of Iowa, 1998. 
elicited a mixed popular response, indicating the transitional nature of Iowans' perceptions of retributive justice in the $1880 \mathrm{~s}^{3}$ Further, an unsuccessful courtroom defense of "insanity produced by masturbation" forced lowans to ponder matters such as insanity and sexuality, revealing underlying legal, medical, and social values.

Viewed most broadly, the case of Chester Bellows illuminates a shifting cluster of contentious sexual, gender, medical, and legal values in late nineteenth-century midwestern society and culture. Most Iowans, regardless of whether they accepted middle-class Victorian notions of gender and sexuality, were horrified by Bellows's departure from gender and sexual norms. They were apparently unsympathetic to the insanity defense, viewing it as a tactic of devious criminals and their defense lawyers, and they strongly supported "rough justice": harsh, communally based, retributive measures against persons who committed serious crimes such as murder. A few middle-class Iowans, however, opposed the death penalty on humanitarian grounds or, short of that, sought to make capital punishment more palatable to middle-class sensibilities. In particular, they were inclined to argue for mercy rather than condemnation for the mentally "defective." In the case of Chester Bellows, then, Iowans espoused competing visions of the nature and appropriate punishment of criminal behavior. Their differing views of Bellows's character, criminality, and death sentence reflected the currents of social and cultural change that influenced the late nineteenth-century Midwest. ${ }^{4}$

3. The last legal execution in Iowa had occurred in Ottumwa on February 17, 1865, when authorities hanged Benjamin A. McComb, convicted in the murder of Laura J. Harvey. Iowa State Register, 16 December 1887.

4. For the historical interpretation of another nineteenth-century court case, one involving child custody, that sparked consideration of contentious social questions, see Michael Grossberg, A Judgment for Solomon: The D'Hauteville Case and Legal Experience in Antebellum America (New York, 1996). For additional treatments of gender, sexuality, and law in the rural Midwest, see Jane $M$. Pederson, "Gender, Justice, and a Wisconsin Lynching, 1889-1890," Agricultural History 67 (1993), 65-82; Joan M. Jensen, "The Death of Rosa: Sexuality in Rural America," ibid., 1-12. An 1892 murder case in Memphis with interesting elements of gender and sexuality, and some parallels with the Bellows case, is analyzed in Lisa J. Lindquist, "Images of Alice: Gender, Deviancy, and a Love Murder in Memphis," Journal of the History of Sexuality 6 (1995), 30-61. 
CHESTER BELLOWS violated many of the sexual norms and gender expectations of Floyd County residents. Before coming to Charles City, a town of nearly three thousand residents in north central Iowa, he had lived with his mother in Minneapolis. Soon after his arrival in the spring of 1886 , the twenty-eightyear-old became attracted to his sixteen-year-old niece, Alice Waterman, who was engaged to a youth her age. After Bellows threatened the younger man, the extended family sought to separate him from Alice by sending him to work on a farm outside of Charles City, while Alice went to work as a domestic servant for the Chester Wilcox family in town. Bellows responded angrily to the family's attempt to end his romantic attachment to his teenaged relative. Alice's mother testified that, looking at Alice, Bellows had shaken his fist and said he would "outrage her before the year passes." Bellows was especially upset with Alice's father, telling Chester Wilcox that "he could cut his [George Waterman's] heart out and kick it all over the prairie." Shortly thereafter, Bellows showed up at the Wilcox house and shot Alice twice, then turned the gun on himself (he sustained only superficial wounds). He later claimed that he and Alice had entered into a suicide pact because "they loved each other so" $^{\prime}$ and because Alice's family treated her poorly.

Two overlapping interpretations of the accused man's sexuality and manhood eventually emerged. His legal defense stated that Bellows had indulged in perverse sexual habits that brought on physical and mental disease resulting in his act of homicide. On the other hand, the prosecution and the press articulated a view of deviant behavior that had much greater resonance with late nineteenth-century Iowans' conceptions of gender roles. That perspective suggested that Bellows's criminality resulted not from mental illness but from an undisciplined, overly "sensual" masculine character rooted in a poorly guided boyhood and adolescence. ${ }^{6}$

5. Trial Transcript, 8, 33, 65, CBF; Floyd County Advocate, 15 December 1887; Iowa State Register, 16 and 17 December 1887 . The 1880 census enumerated 2,421 residents in Charles City, among 14,677 in Floyd County in 1880; and 2,802 residents in Charles City and 15,424 in Floyd County in 1890. Eleventh Census of the United States (Washington, DC, 1895).

6. Trial Transcript, CBF; Floyd County Advocate, 15 December 1887; Iowa State Register, 16 and 17 December 1887. 
The defense lawyer, A. M. Harrison, stressed evidence that Bellows had started practicing masturbation at puberty, which led him into further sexual "dissipation" and possibly into the contraction of venereal disease. In time, masturbation purportedly produced symptoms of insanity, which may also have been exacerbated by the effects of gonorrhea or syphilis. Harrison introduced into court evidence excerpts from articles in standard medical textbooks and encyclopedias linking masturbation and insanity. One entry, from John R. Reynolds's System of Medicine, declared that "self abuse in men is the cause of a particularly disagreeable form of Insanity, characterized by intense self-feeling and conceit, indolence and vacillating of character, and profound moral disturbance in the earlier stage, and later, by failure of intelligence, nocturnal hallucinations, and suicidal or homicidal propensities." ${ }^{17}$ Dr. Gershom H. Hill, superintendent of the Iowa Hospital for the Insane at Independence, concurred, testifying that

masturbation often times produces a morbidness of the nervous system, also of the mind, it often contributes towards producing insanity and occasionally may be the sole cause of insanity. . . . it produces anemia or lack of blood in the body, lack of strength to perform a great amount of mental labor; it produces a disposition to withdraw from society, lead a solitary life, especially a lack of courage to go into the society of young ladies, those who are of good character; it produces a guiltiness of conscience which shows, manifests itself in the eye.

Defense attorney Harrison asserted that numerous manifestations of this "alienation of the mind" stemming from "selfabuse" could be found in Bellows's behavior. He would not, for example,

7. The entry from John R. Reynolds's System of Medicine (1800), vol. 1, is quoted in Trial Transcript, 379, CBF. A concern with masculine sexual selfcontrol and warnings against the alleged physical and mental dangers of masturbation, which ostensibly "depleted the total [bodily or somatic] energy system, leaving fewer resources for productive labor," permeated nineteenthcentury prescriptive and medical literature. John D'Emilio and Estelle B. Freedman, Intimate Matters: A History of Sexuality in America (New York, 1988), 68-69.

8. Trial Transcript, 356, CBF. 
apply himself to manual labor but has been vascilating [sic] in his purposes, shiftless, rather solitary in his habits ... in the busy season of the year and during working hours went about the neighborhood playing on a mouth organ; was ... rarely ever known to seek the society of respectable young ladies, like men of his age and in a creditable manner. . . . he manifests an unnatural intimacy or affection for his niece 16 years of age after he had been requested to stop such foolish conduct."

The defendant's mother testified that she had noticed indications of masturbation and that her son complained of physical problems possibly stemming from sexually transmitted disease. He was listless, "never took a girl no place," complained of "heart and head" illness, threatened suicide, and used a battery to generate electricity to treat his nerve condition. However, three medical experts-superintendent Hill and Charles City physicians S. R. Hewett and I. W. Smith-testified that they had examined the accused murderer and found no physical symptoms of excessive masturbation or venereal disease."

The prosecuting attorney and newspapers that covered the story expounded an explanation for Bellows's behavior that corresponded much more fully with popular notions of the origins of criminal behavior than the defense's argument had. In this moralistic version, Bellows's biography offered significant clues for why he would have murdered his young niece. Bellows was born in the state of New York, and his father died in the Civil War. ${ }^{11}$ He spent parts of his youth in upstate New York, in Charles City, and in Minneapolis. Commentators traced Bellows's failed manhood to the early death of his father, a childhood lacking proper moral direction, an unhealthily close relationship with his mother, and the morally deficient urban environments of Minneapolis and Rome, New York, in which he was raised. ${ }^{12}$ Accordingly, a Charles City newspaper reporter,

9. Ibid., 391, CBF.

10. Ibid., 235-78, 355-440, CBF.

11. A newspaper source lists Rome, New York, as his birthplace, but Bellows's mother testified that her son was born in Rochester, New York. Floyd County Advocate, 15 December 1887; Trial Transcript, 232, CBF.

12. Trial Transcript, 23, 229, 232-35, CBF; Floyd County Advocate, 15 December 1887; Iowa State Register, 16 and 17 December 1887. 
writing on the eve of Bellows's execution, offered the following account of the development of the condemned man's character:

The element of destructiveness was early observed by all, in Bellows. He was peaceable when he had his own way, but beligerent [sic], threatning [sic] and cruel when opposed. In boyhood he delighted in ferocious things, such as killing dogs, pigs, catching birds and feather plucking them and seeing their nude bodies fly away. ... [ [He] was quarrelsome and fighting with companions and members of the family, except his mother to whom he always exhibited unusual manifestations of filial constancy, love and devotion. ${ }^{13}$

Bellows also had participated in a youthful, urban, workingclass subculture in Minneapolis whose practices struck at least some Iowans as decadent and corrupt. For example, an Iowa State Register correspondent asserted, not quite accurately, that Bellows "had learned his lessons of unbridled passions on the streets and in the slums of great cities, and the end is but a legitimate result of that education." Bellows had, in fact, lived in boardinghouses in a working-class district of Minneapolis. Later, according to the testimony of Alice's father, George Waterman, he boasted of a "baudy" and "rough life" in Minneapolis; he bragged, for example, that police had checked under his bed at a residential hotel, and that he had managed to outwit them. ${ }^{14}$

Bellows apparently struggled, in an especially intense way, with the emotional pressures faced by many young men in the late nineteenth century. At that time, Anthony Rotundo argues, as youth attempted to establish themselves in a career or occupation, they were torn between delaying marriage and sexual desires inhibited by social strictures against premarital sexual relations. At a time when matrimony represented "a mark of full manhood," Bellows had not married, had not successfully courted a young woman, and had not secured a place in a trade

13. Floyd County Advocate, 15 December 1887.

14. Iowa State Register, 17 December 1887; Trial Transcript, 261, 177, CBF. In Minneapolis, Bellows had belonged to the Sons of Veterans, one of many urban voluntary associations that single young men joined, according to historian Anthony Rotundo, as a substitute for "the nurture associated with home and family." E. Anthony Rotundo, American Manhood: Transformations in Masculinity from the Reoolution to the Modern Era (Chicago, 1990), 63. 
or occupation, instead working odd jobs and performing sporadic farm labor. His attachment to his mother seemed to be a particularly strong indication of emotional dependency and insufficient maturation into manhood. Moreover, his recourse to masturbation and "dissipation," that is, nonmarital sexual relations, seemed, by contemporary standards, to demonstrate insufficient manly "self-control" over his sexual urges. ${ }^{15}$

Bellows's alleged descent into sexual depravity and homicide supposedly offered a stern lesson for Iowa youth and their parents. In keeping with Victorian values that stressed the importance of the direction provided by a distant but disciplinarian father and an omnipresent and nurturing mother, the defendant's "sensuality and criminality" provided frightening evidence of the deadly effects of an improper childhood and adolescent environment. To avoid similar tragedies in the future, a Charles City newspaper writer advised Iowa boys to "choose virtues [sic] paths" under careful parental guidance. ${ }^{16}$

Chester Bellows's trial included significant testimony concerning premarital sexual relations and aberrant masculine sexuality that transgressed accepted late nineteenth-century notions of decency and decorum. Witnesses spoke with perhaps surprising frankness about deviant sexual practices, sexually transmitted diseases, and illicit sexual intercourse. The Floyd County Advocate, which printed thorough summaries of the trial proceedings, omitted many of these "unfit" parts." Alice Wa-

15. Rotundo, American Manhood, 110-16; Trial Transcript, 166, 181, CBF; Iowa State Register, 17 December 1887; D'Emilio and Freedman, Intimate Matters, 68-69. The average age of marriage for northern males in the nineteenth century was the middle to late twenties. Rotundo also asserts that American men and women had developed a notion of "romantic love" by the nineteenth century, casting aside religious and economic claims to primacy in the determination of marriage partners. Bellows certainly acted on the ideal of romantic love in pursuing a culturally and socially inappropriate relationship with Alice Waterman.

16. Floyd County Advocate, 15 December 1887. For the prescribed Victorian roles for parents raising young boys, see E. Anthony Rotundo, "Boy Culture: Middle Class Boyhood in Nineteenth Century America," in Mark C. Carnes and Clyde Griffen, eds., Meanings for Manhood: Constructions of Masculinity in Victorian America (Chicago, 1990), 26-29.

17. Floyd County Advocate, 18 November 1886. The most explicit aspects of the testimony dealt with the defendant's sexual dysfunction. See, for example, the testimony of Bellows's mother and of Dr. I. W. Smith in Trial Transcript, 
terman's mother, Sarah, and sister, Hattie, testified that Bellows had chloroformed the family dog so that he could slip into Alice's bedroom and spend the rest of the night in bed with her, something that he had apparently done before. George Waterman, Alice's father, recounted how Bellows bragged about his sexual exploits, including those with a "Christian girl [who] went to meeting every Sabbath evening" and additional "conquests with reference to the hired girl." There were hints that Bellows was not the only one in the Watermans' neighborhood engaging in illicit sex. In his testimony, Bellows angrily protested that the Waterman girls "are very wild and are going with every young man in the neighborhood." Suspecting sexual activity among young men and women in the neighborhood, Bellows declared that he would shoot several teenaged boys and the Waterman girls if he "caught them doing anything wrong." Chester Wilcox confirmed on the stand that he had heard. stories that teenaged girls in the neighborhood were "a little inclined to be wild," which he interpreted as meaning "fast after the boys." ${ }^{118}$

Trial testimony raised additional questions about sexual activity in the neighborhood. Following a time-worn pattern in legal cases involving sexual issues, with female accusers and male defendants, Bellows's defense lawyer tried to impeach Alice and Hattie Waterman's moral character and sexual virtue, but the judge did not allow him to pursue this line of questioning very far. ${ }^{19}$ The Waterman sisters were not the only persons whose moral character was questioned. Chester Wilcox also

239-43, 275-77, and 415, CBF. The lawyers' ignorance of human anatomy and disease contributed to several awkward moments in court proceedings. At one point the prosecution queried Dr. Smith, "Does long continued mastirbation [sic], as a general rule produce atrophy of the intestines?" Smith, recognizing that his questioner meant "testes," replied, "No sir. I think you used the wrong word." Later, defense attorney Harrison wondered "if gonorrhea can be produced by masturbation," and Smith patiently responded, "No, sir." When the defense attorney asked Smith whether "the practice of that vice [masturbation] might produce and frequently does, an elongation of the prepuce [foreskin of the penis], Smith replied, "It was rather long, yes, I am not certain whether the practice caused it or that caused the practice." Trial Transcript, 414, 417, 420, CBF.

18. Trial Transcript, 308-16, 170, 176, 402, 408, 54, 159-62, CBF.

19. Ibid., 148, CBF. 
testified for the defense that six to nine years earlier he had heard "married members" of the neighborhood question Alice's father's "reputation as to liscentiousness [sic]." Bellows also claimed, among other allegations of poor treatment of Alice, that her father had told improper stories about her. ${ }^{20}$

Premarital sexual relations and an ethic of masculine sexual virility in rural Floyd County contradicted Victorian middleclass standards, which dictated manly self-control and the sexual exclusiveness of marriage. The contradiction between ideals for sexual behavior and the reality of neighborhood sexual activity, combined with the personal frustrations of his liminal social and generational status, filled out the context for Chester Bellows's actions. ${ }^{21}$

IN ADDITION to linking criminality, sexual habits, and a poorly formed masculine character, the defense and prosecution strategies in the trial illuminated Iowans' attitudes toward mental illness and the reception of the insanity plea in midwestern courts in the late nineteenth century. The defense sought to prove that their client exhibited a long-term pattern of unstable and unusual behavior and that such behavior was symptomatic of insanity. Defense attorney Harrison asserted that a series of false claims Bellows had made about Alice Waterman and other persons in the neighborhood indicated that he was suffering from delusions. The prosecution emphasized, on the other hand, that the defendant had had an intimate relationship with Alice Waterman, that he was angry at her family after being separated from his niece, and that his fears concerning Alice were not delusional but rather were based in reality. In sum, testimony for the prosecution underlined the rational, if passionate and debased, nature of Bellows's crime. ${ }^{22}$

The role of expert testimony in the trial underscores the limited resources available to the criminal justice system in rural Iowa. Three physicians testified concerning Bellows's physical

20. Ibid., 164, CBF.

21. For an "ethic of male aggression" in the nineteenth century that counteracted middle-class ideals, see E. Anthony Rotundo, American Manhood, 121-23.

22. Trial Transcript, CBF. 
and mental condition, and two of them served as both prosecution and defense witnesses. When testifying for the defense, they offered evidence that supported the plea of insanity. When speaking for the state, the experts strongly qualified their previous statements. ${ }^{23}$ Further, only one of the experts, Dr. Gershom Hill, superintendent of the Iowa Hospital for the Insane, possessed any expertise on the subject of mental illness, as the other physicians were general practitioners. In the late nineteenth century, asylum directors such as Hill were a conservative force in the developing field of psychiatry. Clinging to strict antebellum notions concerning the origins and symptomatology of mental illness, asylum doctors rejected the innovative theories proposed by "neurologists" who stressed myriad environmental, physical, and hereditary causes and manifestations. ${ }^{24}$

Strangely, the trial did not delve into the contentious issue of the legal definition of insanity. In most American jurisdictions, criminal courts applied the so-called M'Naghten Rule, which narrowly construed criminal responsibility as the defendant's awareness that their act had consequences and was unlawful. This legal principle of insanity was far narrower than evolving medical understandings of mental illness, and became

23. Ibid., 379-440.

24. "Alienists" such as Hill did reject older theories stressing emotional and environmental influences. For a discussion of the range of views of mental illness in the infant psychiatric profession in the early 1880 s, the debate over the legal definition of insanity, and the popular response to the trial of Charles Guiteau, the unquestionably mentally ill assassin of President Garfield whose defense of insanity also failed to convince a jury, see Charles E. Rosenberg, The Trial of the Assassin Guiteau: Psychiatry and Law in the Gilded Age (Chicago, 1968), esp. 43-74. As with Bellows, the press explained Guiteau's criminality in moral terms, concentrating on an alleged lack of self-discipline and corrupt masculine character. Unlike Bellows's trial, however, Guiteau's case received national publicity, and prosecution and defense summoned the foremost experts in psychiatric medicine to testify. For additional treatments of the historical evolution of attitudes towards mental illness and the field of psychiatry in nineteenth-century America, see Gerald N. Grob, The State and the Mentally Ill: A History of Worcester State Hospital in Massachusetts, 18301920 (Chapel Hill, NC, 1966); idem, Mental Institutions in America: Social Policy to 1875 (New York, 1973); idem, Mental Illness and American Society, 18751940 (Princeton, NJ, 1983); David J. Rothman, The Discovery of the Asylum: Social Order and Disorder in the New Republic (Boston, 1971), 109-54; Elizabeth Lunbeck, The Psychiatric Persuasion: Knowledge, Gender, and Power in Modern America (Princeton, NJ, 1994), 3-24. 
an issue in a number of late nineteenth-century trials where defendants claimed innocence by reason of insanity. ${ }^{25}$

But perhaps most damaging for Bellows's defense was that he acted unbalanced in court and in prison, engaging in "contortions" and "wild howlings." Witnesses testified that he had never behaved that way before he was imprisoned. Indeed, fellow prisoners said that Bellows had told them he was going to "play crazy" in order to get off, and the physicians stated that they regarded his behavior as voluntary in nature. Newspaper correspondents characterized his actions as a pathetic attempt to feign mental illness. In the final analysis, Bellows's long-term pattern of behavior as described by his mother and other family members suggests that he did suffer from some variety of mental disorder that may have played a role in his act of homicide. ${ }^{26}$

The decision did not come easily for the jurors who deliberated over Bellows's fate; they reportedly took eighteen ballots before deciding on a verdict of guilty with capital punishment. Most Charles Citians and most Iowans apparently agreed that Bellows should be executed for his crime. The Iowa press in the 1880 s commonly complained that murderers too often escaped the gallows through the "insanity dodge" and the supposedly inappropriate humanitarianism of governors, judges, and juries. Yet a small group of elite professionals in Charles City opposed the death sentence.

One of the most influential voices raised in opposition to Bellows's sentence was that of B. F. Wright, editor of the Floyd County Advocate and a prominent prohibitionist. In a letter to Governor William Larrabee, Wright argued that Bellows's death sentence should be annulled because he was on the "border line between idiocy and sanity." An editorial in Wright's newspaper deplored the convicted murderer's moral failings and characterized him as a member of a parasitical criminal class "who maraud and do deeds of piracy on society." But the Advocate

25. Rosenberg, The Trial of the Assassin Guiteau, 43-74. Dr. I. W. Smith noted in his testimony that there was a distinction between the legal and medical definitions of insanity, but the defense attorney would not let him pursue the issue. Trial Transcript, 394, CBF.

26. Trial Transcript, 320-32, 355-440, CBF; Floyd County Advocate, 18 November 1886 and 15 December 1887; Iowa State Register, 16 and 17 December 1887. 
pushed the argument further, linking the murder of Alice Waterman to a series of social and political circumstances that allegedly promoted the degeneration of youthful character.

The conditions of society are measurably responsible for the existence of those of his [Bellows's] class. ... Society, in a thousand ways, is doing its very uttermost to commission them for lives of plunder and blood. Look at the partitions that are built higher and broader year by year, between poverty and wealth; look at the honors bestowed on the man whose uncounted capital was procured by purchased and legalized robbery of mankind; look at the worship service continuously rendered to the god of gold; . . look at the prevailing cowardice of public men in espousing and defending the moral reformatory measures and policies demanded by the better and truer civilization of the age; look at the tendency of numerous communities to endorse contempt and violations of law; look at the people who legalize rum holes, dives and dens for the destruction of the youth of the land; ... look at every man who practices the doctrine of "each man for himself and the devil for the hindermost" which pervades society.

The Charles City editor thus tied criminal behavior to societal problems that could be solved only through a broad reform agenda that included antimonopolism, an inflationary monetary policy, the redesign of prisons and the criminal justice system, and strict enforcement of prohibition laws. For the Advocate, the problem lay less with individual depravity and wrongdoing than with corrosive social conditions that needed to be thoroughly revamped through enlightened laws and institutions. ${ }^{28}$

A local judge, Robert Reiniger (not the judge in the Bellows case), also opposed Bellows's execution. In a letter to Governor

27. B. F. Wright to Governor William Larrabee, in folder 1, CBF; Floyd County Advocate, 18 November 1886. In the same issue of the paper in which he covered Bellows's execution, Wright expressed dismay that the accused murderer of prohibitionist George Haddock had been acquitted in Sioux City. Floyd County Advocate, 15 December 1887.

28. Floyd County Advocate, 18 November 1886. For antimonopolism and contention over monetary policy in late nineteenth-century Iowa, see Leland L. Sage, $A$ History of Iowa (Ames, 1974), 186-99. For prohibitionism and its opponents, see ibid., 203-4; Dorothy Schwieder, Iowa: The Middle Land (Ames, 1996), 212-17; and Richard Jensen, "Iowa, Wet or Dry? Prohibition and the Fall of the GOP," in Marvin Bergman, ed., Iowa History Reader (Ames, 1996), 263-90. 
Larrabee, he opined that Bellows was not insane in the technical sense, but that his "mental facilities and perceptions are very weak" and that the "animal' in his nature predominates and controls him." Reiniger asserted that no public good would come from hanging the "imbecil" [sic] but that Bellows should remain imprisoned for life in order to "protect society." While the Floyd County Advocate acknowledged that the sentence was unquestionably "in accord with an outraged public sentiment," Judge Reiniger insisted that his opinion was "the sentiment of the better element of the people here." However, after the Floyd County sheriff advised the governor that no further investigation of the question of Bellows's sanity was necessary, Governor Larrabee declined to intervene, and the execution proceeded. ${ }^{29}$

THE DEBATE over Bellows's sanity and death sentence paralleled a broader debate over retributive justice in Iowa in the late nineteenth century. Lynch mobs murdered twenty Iowans between 1883 and 1895, and lynchers and their apologists defended mob justice as an appropriate response to the state's rare use of the death penalty. "Rough justice" proponents insisted that lynchings deterred murderers and were a valid alternative for protecting society when the state was lax in applying the death penalty. When legal hangings did occur, rough justice advocates demonstrated their commitment to a popular role in the administration of the execution rite by thronging the streets surrounding enclosures that held the gallows. ${ }^{30}$

29. Robt. G. Reiniger to Governor William Larrabee, 3 December 1887, and Floyd County Sheriff W. F. Clark to Governor William Larrabee, 9 December 1887, in folder 1, CBF; Floyd County Advocate, 15 December 1887; Iowa State Register, 16 December 1887. The opposition of elite Charles Citians to the death sentence was replicated in 1907, when a Charles City mob lynched James Cullen, who had murdered his wife and stepson. Most Charles City residents apparently supported the lynching, while a small group of elite professionals vehemently deplored it as atavistic and a mockery of justice. See Michael James Pfeifer, "Iowa's Last Lynching: The Charles City Mob of 1907 and Iowa Progressivism," Annals of Iowa 53 (1994), 305-28.

30. See Pfeifer, "Iowa's Last Lynching." For a discussion of the class base for the cultural chasm over retributive justice as displayed in the debate over lynching and the death penalty in Iowa, especially in the $1880 \mathrm{~s}$, see Michael J. Pfeifer, "Lynching and Criminal Justice in Regional Context: Iowa, Wyoming, and Louisiana, 1878-1946" (Ph.D. diss., University of Iowa, 1998), chap. 1. 
Not surprisingly, then, rumors circulated in the weeks after Bellows's crime that an attempt would be made to lynch him, but a mob never gathered. However, a large crowd did assemble at the train depot to view Bellows's arrival from the state penitentiary in Anamosa in the hours before his execution. Law officers quickly hurried him past what the press characterized as a "mob." The crowd of more than four hundred persons who later surrounded the jail apparently assumed that they would be allowed to watch the execution, but guards kept them at a "safe distance" from the enclosure as the sheriff performed the legal hanging shortly before 11 a.m. ${ }^{31}$ The next day a Des Moines editorialist expressed the perspective of rough justice supporters.

During the carnival of crime that raged a few years ago a distinguished criminal impudently and defiantly remarked that hanging was played out. For twenty-two years it has looked as if that might be true in Iowa, but Chester Bellows, who was hanged at Charles City yesterday, found it differently. There has been too much of a feeling that not only capital punishment was played out, but that punishment of any kind was practically impossible under existing laws and present methods of administering them. ${ }^{32}$

Backers of the death penalty and apologists for lynching responded to a predominantly urban middle-class movement that sought in the last decades of the nineteenth century to modify Iowa's criminal justice system to conform to bourgeois capitalist values. Middle-class reformers such as B. F. Wright and Judge Robert Reiniger stressed the human dignity of the defendant and the importance of due process as they routinely petitioned governors for clemency in death penalty cases and denounced lynchings as dangerous threats to the legal system. Indeed, reformers, arguing on humanitarian grounds, temporarily persuaded the state legislature to abolish the death penalty in $1872 .^{33}$

31. Floyd County Advocate, 15 December 1887; Iowa State Register, 16 and 17 December 1887.

32. Iowa State Register, 17 December 1887.

33. Petitions for pardon in the classified files of death row inmates Chester Bellows, Henry Schmidt, James Dooley, and A. K. Cumberland, in Governor's Office, Records and Correspondence: Criminal Matters, State Historical 
Antebellum executions in Iowa had been extremely popular events that drew thousands of people to observe a ceremony rich in implications for public justice. Reformers attempted to sanitize the death rite by purging it of its festive, participatory trappings and its latent threat of public disorder. Thus, even though rough justice proponents successfully convinced the legislature to restore the death penalty in 1878 , the new statute specified that executions must be performed within an enclosure before only a small number of select witnesses. In 1894 the legislature went even further, largely divorcing retributive justice from its local basis by removing executions from the counties to the state penitentiary in Fort Madison. ${ }^{34}$

In long-term perspective, then, reformers and rough justice proponents fought a rhetorical and, at times, physical war in the late nineteenth century through newspaper columns, prolonged deliberations over death sentences, and lynchings. By the second decade of the twentieth century, myriad legal and cultural changes had ended lynchings and transformed legal executions into centralized, carefully controlled, and concealed affairs. Iowans replaced an expansive conception of a popular, localized role in the performance of capital punishment with an acceptance of the nearly exclusive responsibility of the state in exacting retribution for serious crimes.

Society of Iowa, Des Moines. For an analysis of the abolition and the restoration of the death penalty in lowa, see Richard Acton, "The Magic of Undiscouraged Effort: The Death Penalty in Early Iowa, 1838-1878," Annals of Iowa 50 (1991), 721-50. Acton writes that a peculiar convergence of circumstances led to the abolition of capital punishment in 1872 . Nonetheless, as he notes, the antigallows movement had antebellum origins in lowa and reflected intellectual and social trends brought by immigrants from northeastern states.

34. Annotated Code of the State of Iowa (Des Moines, 1897), 1,884-85. For the public spectacle of an antebellum execution attended by approximately ten thousand persons, see the account of the legal hanging of William Hinkle on August 13, 1858, in Appanoose County in Pioneer History of Davis County, Iowa (Bloomfield, 1927), 374-78.

35. Again, for a much fuller treatment of these issues in postbellum Iowa, see Pfeifer, "Lynching and Criminal Justice in Regional Context," chap. 1. Louis P. Masur, Rites of Execution: Capital Punishment and the Transformation of American Culture, 1776-1865 (New York, 1989), offers a large-scale perspective on alterations in capital punishment practices. 
THE TRIAL AND EXECUTION of Chester Bellows thus marked a transitional phase in Iowans' attitudes about crime and punishment. Popular preconceptions and deficient court resources colored the consideration of Bellows's claim of insanity. As in most Iowa death penalty cases in the late nineteenth and early twentieth centuries, strongly held conceptions of sexual and gender roles also influenced Bellows's death sentence. Tellingly, five of the six men legally hanged in Iowa between 1887 and 1909 had killed women. The murder of a woman by a man provoked a harsher and more systematic social control response than same-sex homicide, as it apparently abrogated important conceptions of the relationship between sexes. ${ }^{36}$

Rough justice advocates differed with elite reformers over whether Bellows should be hanged, continuing a debate over the nature of criminal justice that raged in Iowa through much of the last third of the nineteenth century. Reformers vainly pleaded with the governor for commutation to a life sentence out of mercy for a mentally defective man. For their part, retributive justice enthusiasts surrounded the Floyd County jail in large numbers and cheered the first execution in Iowa in two decades, declaring that "Bellows received naught but what he justly deserved. ${ }^{\prime 3 ?}$

36. For an inventory of Iowa executions, see M. Watt Espy and John Ortiz Smykla, Executions in The United States, 1608-1991: The Espy File, bcomputerfilec, 3d ICPSR ed. (Ann Arbor, MI, 1994).

37. Iowa State Register, 17 December 1887. 
Copyright of Annals of Iowa is the property of State of Iowa, by \& through the State Historical Society of Iowa and its content may not be copied or emailed to multiple sites or posted to a listserv without the copyright holder's express written permission. However, users may print, download, or email articles for individual use. 